\title{
Kudus Local Wisdom Representation and Character Education Value in Folklore Ki Ageng Bendokerep
}

\author{
Nova Daniar Adriyanti ${ }^{1}$, Sarwiji Suwandi ${ }^{2}$ and Slamet Subiyantoro ${ }^{3}$ \\ \{novadaniar@student.uns.ac.id ${ }^{1}$, sarwijiswan@staff.uns.ac.id ${ }^{2}$, \& \\ s.biyantoro@staff.uns.ac.id $\left.{ }^{3}\right\}$ \\ ${ }^{1,2,3}$ Sebelas Maret University, Indonesia
}

\begin{abstract}
Folklore is one of cultures which develops in an area. The existence of folklore nowadays almost comes to an extinction because it is not kept and preserved. As the consequence, the society is lack of awareness in applying the local wisdom contained in the folklore into their daily life. This research was conducted as the form of effort to make the society has view or positive thought. Beside that, it is also as the learning by applying the value of local wisdom, and the value of character education in it. This research aims to describe the value of local wisdom and the value of character education in folklore as one of alternative media and can be used as the guideline in the society. The form of this research was qualitative by using etnography research strategy. Data were obtained through interview and observation. The results of this research found out some value of local wisdoms; (1) work hard value, (2) discipline value, (3) peace value, (4) honesty value, and (5) grateful value. Character education value; (1) religious value, (2) peace of love value, (3) social care value, and (4) responsibility value.
\end{abstract}

Keywords: local wisdom value, character education value, folklore, Ki Ageng Bendokerep, Javanese culture.

\section{INTRODUCTION}

Folklores are all forms of prose, written or oral narration, that have been passed down through the years. Folk stories can be in the form of regional songs, stories, puzzles, proverbs, or other things stored in words or writings [1]. In India, folklore means tales, legends, and superstitions about certain ethnic groups, as well as in Indonesia [2]. The phenomenon of society's appreciation of folklore in the regions has been decreased. People stories, that are one of the cultures that live in their society, are now almost extinct. This is because folklore is displaced by technological developments that take modern stories [3]. As a result, the development of the folklore has obstancles due to just some people who know it. The survey conducted by the author that $90 \%$ of children are more fond of things that are modern. Very few children today listen to and appreciate folklore in their area. They feel strange with the local culture in their area. The fact is, if studied further, in folklore there are many life philosophies, local wisdom, and positive values underlying their lives that can be used as a reflection of life in the future. Folklore contains great value that is owned by the society [4]. 
Local wisdom as a reflection of the local society culture can be explored through stories that develop in an area. Thus, local wisdom is closely related to folklore. Local wisdom is a view of life and science and various life strategies in the form of activities done by local society in answering many problems in their needs [5]. Knowing local wisdom in folklore can make a positive view for the society to reflect positive values towards folklore. Local wisdom can be used to keep the social harmonization as it can minimize the conflict in the society [6]. The concept of society culture has been developed using culture as the core, and adapting local wisdom [7]. This is done so that the society can appreciate folklore that is now almost extinct because it is not preserved. One way to keep folklore exist in society is by appreciate it. There are many ways to appreciate folklore, for example by introducing the story to the next generation and teach them the positive values that exist in folklore. Local wisdom in folklore can be an effort for students both directly and indirectly to preserve local wisdom. In addition, it can improve students understanding and strengthen the character of students during classroom learning activities [8].

Kudus is a district that is rich in folklore. However, it is a pity that folklore has not been touched by the younger generation because they do not know the existence of folklore in their area. Folklores can be taught in education. Through learning Indonesian language the values of local wisdom can be embedded and the value of character education especially in folklore material. The role of the character education is as the basis and guidelines for teachers to form students' character [9]. Figures presented by folklore are very diverse, ranging from animals, humans, gods, even spirits [10]. Character of the figures in folklore can be used as student learning because it reflects positive traits that can be followed and there are negative traits that can be avoided. Folklore contains values and messages in it, namely inculcating character education to children [11]. Messages in folklore can be used as learning for society life [12]. $K i$ Ageng Bendokerep folklore contains the local wisdom value and character education value in it. This is the reason why the author took the title. Ki Ageng Bendokerep folklore is a story from Kudus.

\section{METHOD}

This research is a descriptive qualitative research with the main focus is to describe the local wisdom value and the character education value in folklore as an alternative to society and education. The main data source is the folklore of Ki Ageng Bendokerep. Folklores are obtained through verbal information from informants that then transcribed into the story in writing and related documents. The research strategy uses ethnography. Data collection techniques are (1) direct observation, (2) recording, interviewing, and recording, (3) documents analysis. Validity techniques use triangulation. Triangulation is used to check the validity of data that functions to compare data by utilizing something else. Triangulation of this research uses data/source dan theory triangulation. The data analysis technique uses an interactive model and the steps are data reduction, data presentation, and conclusion [13].

\section{RESULT AND DISCUSSION}

This folklore entitled Ki Ageng Bendokerep from Kudus Regency, Central Java. The story is in Bendokerep Village, Karangbener Subdistrict, Kudus Regency. This story tells of a knight who had a noble mind and character named Ki Ageng Singo Wijoyokusumo and was often called Ki Ageng Bendokerep. This story is categorized in legend. Legend is a folklore 
whose characters are human, although there are times when they have extraordinary traits and are often also helped by magical creatures.

\subsection{Local Wisdom Value of Folklore Ki Ageng Bendokerep}

a. Hard Work Value

The hard work value is a behavior of doing or coducting activities seriously, with optimal efforts to achieve the purposed goals. Proved by the following quote:

"Ki Ageng was serious about educating the students to become young people who were warrior-minded and noble in character. He taught earnestly so that his students became smart. The hard-working of Ki Ageng paid off, his students then became great knights and had virtuous character".

\section{b. Discpline Value}

The discipline value is the behavior of being obedient to the values that are believed to be the responsibility. Proved by the following quote:

"Ki Ageng never suffers and always do his obligation to teach his students to be able to. His desperate perseverance greatly motivates his students so that they always learn and become human beings who have good manners".

\section{c. Peace Value}

The value of peace is a peaceful life without something disturbing. Proved by the following quote:

"Narrated in the valley of Mount Muria there is a group of people who live simply in peace and serenity".

\section{d. Honesty Value}

Honesty value is a character that is not lying and can be trusted. Proved by the following quote:

"Ki Ageng Bendokerep is also one of the trusted people of Sultan Pajang. He has asked to protect the safety of Raden Ayu Srimpi who lives in Kadisono Langensuko Hall. In addition, he was also entrusted to maintain the peace of the people around the princess's residence".

\section{e. Gratitude Value}

Gratitude value is expression to reflect a sense of gratitude to God for the achievements that have been reached in life. Proved by the following quote:

"with its presence, the society feels protected from the disturbances of robbers and people who have evil intentions. The society is grateful for the presence of Ki Ageng who is able to protect the public from evil external attacks".

The local wisdom value is the value that is born in the society. Through Ki Ageng Bedokerep folklore, five values are found in the local wisdom value; (1) the hard work value, (2) the discipline value, (3) the peace value, (4) the honesty value, and (5) the gratitude value. The survey found by the author that $27 \%$ of the value of local wisdom is applied in folklore. The local wisdom value can be applied in many ways. The application of local wisdom as ecology, nature conservation, customary environmental preservation, part of life and the source of life that must be preserved [14]. Local wisdom is believed by the society to be able to help ecology, nature conservation because the society knows the stages of applying local 
wisdom in the fields of ecology and conservation. The policies applied by the society are hereditary so they are arranged in implementing environmental preservation [15]. Local wisdom can be applied as a strategy for tourism so that it can continue to be preserved and maintained [16]. The local wisdom can be used as a solution to conflicts within the society [17]. This is done so that the society has tolerance so that people can create harmony and peace. Wisdom values have their own goals in their application. In this research, the authors chose to apply the value of local wisdom in folklore so that the folklore did not missing and the society always preserved.

\subsection{Character Education value of Folklore Ki Ageng Bendokerep}

a. Religious Value

The religious value is that God is seen as a substance that gives help to humans in guiding his people to get salvation. Proved by the following quote:

"Once upon a time, he was one of the students of Sunan Muria who had been given permission to spread religious knowledge to the society by becoming the leader of the hermitage which he pioneered in the valley of Mount Muria".

\section{b. Peace of Love Value}

The peace value is the attitude of someone who shows pleasure, calm, and happy with each other. Proved by the following quote:

"with his presence, the society feels protected from the disturbances of robbers and people who have evil intentions".

c. Social Care Value

The social care value is responsive, caring, and loving sharing in people's lives. Proved by the following quote:

"He is known to have a virtuous person, likes to help people who are in a state of hostility, close to the society, very responsible and trustworthy to maintain the safety of every citizen".

\section{d. Responsibility Value}

The responsibility value is a reflection of a person to bear the duties and responsibilities. Proved by the following quote:

"Its establishment is very strong. He will not be affected by enemy seduction even though his safety is threatened. Always prioritizing the interests of the society".

The character education value in Ki Ageng Bendokerep folklore is (1) religious values, (2) peace of love value, (3) social care value, and (4) responsibility value. Through the value of character education can build better behavior of children. The world of education plays an important role in forming the character of children. Society nowadays, especially adolescents, has a habit to follow the development of a trending lifestyle, from how to dress, style of speech, association that always follows the development of science and technology, as well as the popular culture from outside [18]. This gives an impact on the decline of the younger generation interest in positive things and the increasing juvenile delinquency. Character education teaches ways of thinking and behaving that help individuals to live and work together as family, society, and state and help them to make accountable decisions [19]. Through learning the value of character education in folklore, students can emulate or reflect the positive character in folklore. The value of character education influences learning 
activities [20]. The negative behavior affects student learning outcomes. It makes the author conduct a research for the inculcating character education through the figure's character.

Folklores are cultures that are inherited from generation to generation. However, this has not been fully done because of many factors that influence. This decline in local culture, especially folklore, inspired the writer to arouse a sense of love for local culture [21]. The local wisdom value in folklore Ki Ageng Bendokerep was first applied to character education in schools. This folklore has a positive element that can build student character so that it can be applied and provide a positive outlook on society. In addition, students can emulate the value of character education through the characters in this folklore. Besides being able to be used as one of the learning media about character education, this folklore can also introduce local culture to children in school so that the next generation is able to maintain and preserve the cultural heritage of the ancestors.

\section{CONCLUSION}

This Ki Ageng Bendokerep folklore is a legend. Found some values that classified into the local wisdom value and character education value. The local wisdom values are (1) hard work value, (2) discipline value, (3) peace value, (4) honesty value, and (5) gratitude value. The character education of it are (1) religious value, (2) peace of love value, (3) social care value, and (4) responsibility value. Through school learning, students are introduced to the Ki Ageng Bendokerep folklore so students can apply character education value to form their behavior and hopefully they can love the local culture, keep, and preserve it. So this folklore can be used as a medium especially in learning Indonesian.

\section{REFERENCE}

[1] A. Mohd Fairuz and P. J. Ng, "A Malaysian Folklore Game Design As A Tool Of Culture Preservation And Entertainment: Toyol,” Adv. Soc. Sci. Educ. Humanit. Res., vol. 207, no. Reka, pp. 198-202, 2018.

[2] P. T.R and H. M. Shivakumar, "Phyto-Ethno-Medicinal Knowledge of Folklore People in Kappathgudda Region of Gadaga District, Karnataka, South India,” Int. J. Adv. Res., vol. 4, no. 12, pp. 1631-1636, 2017.

[3] P. I. Safitri, S. Suwandi, and N. E. Wardani, “Aktualisasi Cerita Rakyat Sebagai Media Pendidikan Karakter pada Siswa Sekolah Dasar di Kabupaten Purworejo/ Folk Stories as a Medium for Character Education in Elementary Schools in the Purworejo Regency," Aksara, vol. 2, no. 2, pp. 66-72, 2017.

[4] H. Hilmiyatun, S. Suwandi, H. Waluyo, and N. Wardani, "The Cultural Representation of Lelakaq Sasak Lombok In The Folklore of Dewi Rengganis (Analysis of Form, Function and Meaning)," Proc. 2nd Work. Lang. Lit. Soc. Educ., 2019.

[5] S. Kusnita, S. Suwandi, M. Rohmadi, and N. Wardani, "The Role of Local Wisdom in the Malay Folklore Mempawah as Base of Character Education on Children in Primary School (Study Folklore in West Borneo)," Adv. Soc. Sci. Educ. Humanit. Res., vol. 158, no. Ictte, pp. 649-656, 2017.

[6] L. Pradita, S. Sumarlam, K. Saddono, and M. Rohmadi, "Strengthening the Character of Students Based on Local Cultural Wisdom in 'Petatah Petitih Sunan Gunung Jati," Proc. Int. Conf. Sci. Technol. Internet Things, 2019.

[7] U. Sungkharat, P. Doungchan, C. Tongchiou, and B. Tinpang-nga, "Local Wisdom : The Development Of Community Culture and Production Processes In Thailand,” Int. Bus. Econ. Res. J., vol. 9, no. 11, pp. 115-120, 2010. 
[8] P. Anggraini and T. Kusniarti, "Character and Local Wisdom-Based Instructional Model of Bahasa Indonesia in Vocational High Schools,” J. Educ. Pract., vol. 8, no. 5, pp. 23 29, 2017.

[9] S. Kamal, K. Saddhono, and S. Suyitno, "Cowongan is the Cultural Heritage of Banyumas: Relevance of Rituals as a part of the Value Character Education," Proc. 2nd Work. Lang. Lit. Soc. Educ., 2019.

[10] Y. Dwinuryati and Andayani, "KAJIAN PENDIDIKAN KARAKTER BERBASIS KEARIFAN LOKAL PADA CERITA RAKYAT 'NYI ANDAN SARI DAN KI GURU SOKA,"” J. Artefak Hist. Educ., vol. 4, no. 1, pp. 15-22, 2017.

[11] M. Syaifulloh, "Character Education By Comprehensive Approach in Local History on the Local Community of Merapi'S Slope in Sleman Yogyakarta,” Proc. Int. Conf. Sci. Technol. Internet Things, 2019.

[12] N. T. Maulana, E. Suryanto, P. Studi, and P. Bahasa, "Analisis Struktural Dan Nilai Pendidikan Cerita Rakyat Serta Relevansinya Sebagai Bahan Ajar Bahasa Indonesia Di SMP," Gramatika STKIP PGRI Sumatera Barat, vol. 4, no. 1, pp. 139-149, 2018.

[13] Sugiyono, "Metode Penelitian Pendidikan Pendekatan Kuantitaif, Kualitatif, dan R\&D," Metode Penelitian Pendidikan Pendekatan Kuantitaif, Kualitatif, dan R\&D. pp. 283-393, 2013.

[14] L. Taena, A. Laepe, L. O. A. Basri, L. Miliha, A. Lio, and I. K. Suardika, "Tradition of 'Falia' Local Wisdom as Cultural Capital in the Formation of Magnanimity of Muna Society," J. Sustain. Dev., vol. 10, no. 5, p. 217, 2017.

[15] Sumarmi, "Local Wisdom of Osing People in Conserving Water Resources," Komunitas Int. J. Indones. Soc. Cult., vol. 7, no. 1, p. 43, 2016.

[16] H. Farhan and K. Anwar, "The Tourism Development Strategy Based on Rural and Local Wisdom,” J. Sustain. Dev., vol. 9, no. 3, p. 170, 2016.

[17] L. Wibawa and H. Hiryanto, "Identification of Local Wisdom Values in the village Bejiharjo for youth education Conflict Resolution,” Adv. Soc. Sci. Educ. Humanit. Res., vol. 66, no. Yicemap, pp. 342-345, 2017.

[18] A. Setiyawan, "Pengintegrasian Nilai Pendidikan Karakter dalam Pembelajaran Bahasa Arab di Pusat Pengembangan Bahasa UIN Sunan Kalijaga Yogyakarta,” J. Pendidik. Islam, vol. 9, no. 2, pp. 127-144, 2015.

[19] L. G. Otaya, "Pendidikan Karakter Berbasis Nilai," J. Pendidik. Islam, vol. 8, no. 1, pp. 75-94, 2014.

[20] M. Goreti and R. Kristiantari, "Development of School Culture as Initial Orientation Strengthening Character Education for Primary School Students," Proc. First Int. Conf. Technol. Educ. Sci., pp. 1-6, 2019.

[21] K. Saddhono and S. Supeni. "The role of dutch colonialism in the political life of Mataram dynasty: A case study of the manuscript of Babad Tanah Jawi." Asian Soc. Sci. vol. 10 no. 15 pp. $1-7,2014$ 